\title{
PENGARUH LINGKUNGAN KERJA TERHADAP KEPUASAN PEGAWAI DENGAN MEDIASI KOMUNIKASI PADA DINAS PERHUBUNGAN KOTA MAKASSAR
}

\author{
Ayub ${ }^{1)^{*}}$, Jannati Tangngisalu ${ }^{2)}$, Elyas Albar ${ }^{3)}$ \\ 1, 2. 3) Program Studi Manajemen, Sekolah Tinggi Ilmu Ekonomi Bongaya Makassar \\ "Email: ayubambapasau@gmail.com ${ }^{1)}$,jannatijamaluddin@gmail.com ${ }^{2)}$ elyasalbar79@gmail.com ${ }^{3)}$
}

\begin{abstract}
Abstrak
Tujuan penelitian ini adalah (1) Untuk mengetahui pengaruh lingkungan kerja terhadap komunikasi pegawai. (2) Untuk mengetahui pegaruh lingkungan kerja terhadap kepuasan pegawai. (3) Untuk mengetahui pengaruh komunikasi terhadap kepuasan pegawai. (4) Untuk mengetahui pengaruh lingkungan kerja terhadap kepuasan pegawai dengan mediasi komunikasi. Sampel dalam penelitian ini berjumlah 65 responden yang merupakan pegawai Dinas Perhubungan Kota Makassar.Analisis regresi linier berganda dengan software SPSS 22 digunakan untuk menguji hipotesis penelitian. Hasil penelitian ini menunjukkan: Lingkungan kerja berpengaruh positif dan signifikan secara parsial terhadap komunikasi, Lingkungan kerja berpengaruh negatif dan signifikan secara parsial terhadap kepuasan pegawai, Komunikasi berpengaruh positif dan signifikan secara parsial kepuasan pegawai, Lingkungan kerja berpengaruh positif dan signifikan terhadap kepuasan pegawai melalui komunikasi sebagai variabel mediasi..
\end{abstract}

Keywords: Lingkungan kerja, Komunikasi, Kepuasan pegawai 


\section{PENDAHULUAN}

Dalam suatu organisasi, baik yang melayani kepentingan publik seperti organisasi pemerintah maupun organisasi swasta, menginginkan adanya sebuah pencapaian yang maksimal yang terkait dengan peningkatan hasil kerja demi tercapainya visi dan misi organisasi. Salah satu kunci keberhasilan tersebut adalah dengan mengelolah sumber daya manusianya dengan sebaik baiknya. Mengelolah sumber daya manusia di antaranya adalah tentang bagaimana upaya yang di lakukan oleh organisasi untuk meningkatkan kepuasan kerja pegawai, karena kepuasan kerja menjadi salah satu pertimbangan penting bagi pegawai untuk loyal dan bertahan pada sebuah organisasi. Kepuasan kerja menjadi topik yang cukup menarik bagi penulis untuk di jadikan suatu kajian dalam sebuah penelitian.Beberapa penelitian sebelumnya menjadi acuan untuk menggali informasi yang menarik mengenai determinan kepuasan kerja pegawai.

Penelitian terdahulu telah membahas mengenai determinan kepuasan kerja. Seperti yang di lakukan oleh Al Musadieq dan Eko (2014) dengan objek penelitian PT.Telkom Indonrsia Tbk, yang menyimpulkan bahwa variabel lingkungan kerja fisik dan non-fisik secara bersama sama berpengaruh signifikan terhadap kepuasan kerja karyawan. Dari penelitian tersebut memberikan wawasan mengenai pentingnya lingkungan kerja terhadap kepuasan kerja pegawai. Namun kepuasan kerja yang di sebabkan oleh lingkungan kerja bersifat dinamis, artinya dapat berubah sewaktu waktu.Oleh sebab itu instansi di tuntut untuk selalu berinovasi dalam menciptakan lingkunga kerja yang nyaman bagi pegawai.

Selain lingkungan kerja yang baik, kepuasan kerja juga sangat di pengaruhi oleh komunikasi. Penelitian sebelumnya yang di lakukan oleh Okta (2016) telah menyimpulkan bahwa komunikasi dapat meningkatkan kepuasan kerja karyawan PT.Pabrik Kertas Setia Kawan Makmur Sejahtera Tulungagung. Hubungan baik antara atasan dan bawahan, adanya umpan balik, iklim komunikasi yang mendukung serta perspektif organisasi yang terarah dapat menambah kepuasan kerja karyawan lebih optimal.

Penelitian ini akan menggunakan objek Dinas Perhubungan Kota Makassar yang terletak di Jl. Mallengkeri No.18, Mangasa,
Kec.Tamalate, Kota Makassar. Alasan pemilihan lokasi ini adalah pertimbangan kepuasan kerja pegawai yang berbeda beda antara pegawai yang satu dengan pegawai lainnya, permasalahan tesebut di sebabkan oleh lingkungan kerja yang belum memadai serta komunikasi yang tidak berjalan maksiamal.

\section{TINJAUAN PUSTAKA}

\section{Kepuasan Pegawai}

Kepuasan kerja merupakan perasaan senang atau gembira, atau perasaan suka seseorang sebelum dan setelah melakukan suatu pekerjaan (Kasmir 2016: 192). Pendapat lain mengenai kepuasan kerja, menurut (Sutrisno 2015): 75) bahwa pada hakekatnya, kepuasan kerja merupkan perasaan senang atau tidak senang pekerja dalam memandang dan menjalankan pekrjaannya, apabila sesorang senang terhadap pekerjaannya, maka orang tersebut puas terhadap pekerjaannya.

Indikator-indikator yang menentukan kepuasan kerja yaitu (Robbins, 2015: 181-182):

a) Pekerjaan yang secara mental menantang, Karyawan cenderung lebih menyukai pekerjaan yang memberi mereka kesempatan untuk menggunakan keterampilan dan kemampuan mereka dan menawarkan beragam tugas, kebebasan, dan umpan balik.

b) Kondisi kerja yang mendukung, Karyawan peduli akan lingkungan yang baik untuk kenyamanan pribadi maupun untuk mempermudah mengerjakan tugas yang baik

c) Gaji atau upah yang pantas, Para karyawan menginginkan sistem upah dan kebijakan promosi yang mereka persepsikan sebagai adil dan segaris dengan pengharapan mereka.

d) Kesesuaian kepribadian dengan pekerjaan, Teori "kesesuaian kepribadianpekerjaan" Holland menyimpulkan bahwa kecocokan yang tinggi antara kepribadian seorang karyawan dan okupasi akan menghasilkan seorang individu yang lebih terpuaskan.

e) Rekan sekerja yang mendukung, Bagi kebanyakan karyawan, bekerja juga mengisi kebutuhan akan interaksi sosial. Oleh karena itu, tidaklah mengejutkan apabila mempunyai rekan sekerja yang ramah dan mendukung akan mengarah ke kepuasan kerja yang meningkat. 


\section{Lingkungan Kerja}

Lingkungan adalah suasana atau kondisi di sekitar lokasi temat bekerja, dapat berupa ruangan, layout, sarana dan prasarana, serta hubungan kerja dengan sesame rekan kerja, Kasmir 2016: 192). Pendapat lain menurut Siagian (2014:56) mengemukakan bahwa lingkungan kerja adalah lingkungan di mana pegawai melakukan pekerjaannya sehari-hari. Menurut (Sedarmayanti, 2011) seorang karyawan mampu melaksanakan kegiatannya dengan baik, sehingga dicapai suatu hasil yang optimal, apabila ditunjang oleh suatu kondisi lingkungan kerja yang sesuai.Suatu kondisi lingkungan dikatakan baik atau sesuai apabila manusia dapat melaksanakan kegiatannya secara optimal, sehat, aman, dan nyaman.

Adapunindikator-indikator lingkungangan kerja Menurut Nitisemito (1992: 159) lingkungan kerja diukur melalui :

a) Suasana Kerja, Hal ini dimaksudkan bahwa kondisi kerja yang ada menyenangkan, nyaman dan aman bagi setiap karyawan yang ada di dalamnya.

b) Hubungan dengan Rekan Sekerja, Hubungan dengan rekan sekerja yang harmonis dan tanpa ada saling intrik sesama rekan sekerja. Salah satu faktor yang dapat mempengaruhi karyawan tetap tinggal dalam satu organisasi adalah hubungan yang harmonis diantara rekan kerja. Hubungan yang harmonis dan kekeluargaan merupakan salah satu faktor yang dapat mempengaruhi kinerja karyawan.

c) Tersedianya Fasilitas Bekerja, Hal ini dimaksudkan bahwa peralatan yang digunaka untuk mendukung kelancaran kerja lengkap atau mutakhir. Tersedianya fasilitas kerja yang lengkap, walaupun tidak baru merupakan salah satu penunjang proses dalam bekerja.

\section{Komunikasi}

Komunuikasi merupakan proses penyampaian informasi dari satu pihak baik individu, kelompok atau organisasi sebagai sender kepada pihak lain sebagai receiver untuk memahami dan terbuka peluang memberikan respon balik kepada sender (Wibowo, 2013: 242). Sementara itu Mangkunegara (2014: 145) berpendapat bahwa komunikasi dapat diartikan sebagai proses pemindahan suatu informasi, ide, pengertian dari seseorang kepada orang lain dengan harapan orang lain tersebut dapat menginterpretasikannya sesuai dengan tujuan yang dimaksud.
NIAGAWAN Vol 9 No 2 Juli 2020

Indikator-indikatorkomunikasi (Muhammad 2011: 43) adalah sebagai berikut:

a) Keterbukaan (opennes) merupakan sikap jujur, rendah hati, dan adil didalam menerima pendapat orang lain.

b) Empati (empathy) adalah kemampuan untuk memahami perasaan orang lain dan kesanggupan untuk menempatkan diri dalam keadaan orang lain.

c) Dukungan (support) adalah suatu bentuk kenyamanan, perhatian, penghargaan, ataupun bantuan yang diterima individu dari orang yang berarti, baik secara perorangan maupun kelompok.

d) Rasa positif (positiveness) Bersikap positif baik ketika mengemukakan pendapat atau gagasan yang bertentangan maupun gagasan yang mendukung, karena rasa positif itu sudah dengan sendirinya mendukung proses pelaksanaan komunikasi yang efektif.

Kesamaan (equality) yaitu siap menerima anggota komunikasi lain sama atau setara.

\section{METODOLOGI PENELITIAN}

\section{Pendekatan penelitian}

Metode penelitian pada dasarnya adalah cara ilmiah untuk mendapatkan data dengan tujuan dan kegunaan tertentu Sugiono (2017: 2). Jenis penelitian yang di gunakan dalam penelitian ini adalah pendekatan kuantitatif dengan penelitian deskriptif.Penelitian kuantitatif adalah penelitian dengan metode statistik untuk menguji hipotesis. Penelitian deskriptif adalah suatu metode dalam meneliti status kelompok manusia, suatu objek, suatu set kondisi, suatu system pemikiran ataupun suatu kelas peristiwa pada masa yang akan datang, tujuannnya adalah untuk membuat deskripsi atau gambaran sistematis dan akurat mengenai fakta-fakta yang terjadi.

\section{Populasi}

Populasi adalah wilayah generalisasi yang terdiri atas : obyek/subyek yang mempunyai kualitas dan karakteristik tertentu yang di tetapkan oleh peneliti untuk di pelajari dan kemudian di tarik kesimpulannya, Sugiyono (2017: 80). Dalam penelitian ini populasi yang di ambil adalah seluruh pegawai kantor Dinas Perhubungan Kota Makassar yang berjumlah 65 orang.

\section{Sampel}

Sampel adalah bagian dari jumlah dan karakteristik yang di miliki oleh populasi tersebut, Sugiyono (2017: 81). Saampel yang di ambil adalah seluruh pegawai kantor Dinas Perhubungan Kota Makassar, dengan 
menggunakan metode sampel jenuh, di mana setiap anggota populasi di pilih menjadi sampel. Jadi jumlah sampel dalam penelitian ini sebanyak 65 responden. Jumlah tersebut dalam rangka memenuhi jumlah minimal dalam sampel dan hal ini untuk dapat memenuhi akan syarat minimum data untuk diolah menggunakan analisis SPSS statistic 22.

\section{Metode pengumpulan data}

Metode pengumpulan data dalam penelitian ini adalah adalah angket atau kuisioner. Kuesioner dilakukan dengan cara mendistribusikan atau memberi seperangkat pernyataan atau pertanyaan tertulis kepada responden untuk dijawabnya secara tertutup dan pengukurannya mengunakan skalaordinal dengan bantuan skala likert yang digunakan untuk mengukur sikap, pendapat, dan persepsi seseorang atau kelompok orang tentang fenomena yang diteliti.

\section{Model analisis data}

Pengujian dalam penelitian ini yaitu melalui uji instrumen yang meliputi uji validitas dan uji realibilitas; uji asumsi klasik yang meliputi uji normalitas, uji multikolonieritas dan uji heteroskedastisitas; analisis deskriptif; uji hipotesis yang meliputi uji kelayakan model (uji F), uji koefisien regresi parsial (uji T), koefisien determinasi $\left(\mathrm{R}^{2}\right)$, dan analisis jalur (path analysis). Pengujian dilakukan melalui SPSS versi 22.

\section{Pengukuran variabel}

Pembuktian kebenaran data yang terkumpul dari responden serta guna memudahkan analisa data, khususnya untuk data-data yang diperoleh melalui angket (kuisioner), maka data tersebut terlebih dahulu ditransformasi kedalam bentuk kuantitatif, yaitu dengan jalan memberi skor pada setiap jawaban dari setiap item pertanyaan yang diajukan kepada responden. Data tersebut akan disusun dalam tabel frekuensi dan persentase untuk semua jawaban responden dari setiap variabel penelitian. Penentuan ini dihitung berdasarkan Skala Likert dimana data yang dikumpulkan dari kuisioner selanjutnya akan diukur dengan bobot hitung 1 (satu) sampai 5 (lima).

\section{HASIL DAN PEMBAHASAN}

\section{Uji asumsi klasik}

Mengingat data penelitian yang digunakan adalah sekunder, maka untuk memenuhi syarat yang ditentukan sebelum uji hipotesis melalui uji $\mathrm{t}$ dan uji $\mathrm{F}$ maka perludilakukan pengujian atas beberapa asumsi
NIAGAWAN Vol 9 No 2 Juli 2020

klasik yang digunakan yaitu normalitas, mulltikolinieritas, autokolerasi, dan heteroskedastisitas yang secara rinci dapat dijelaskan sebagai berikut.

\section{Uji Normalitas}

Uji asumsi normalitas bertujuan untuk menguji apakah dalam model regresi, variabel pengganggu atau residual memiliki distribusi normal atau tidak. Distribusi normal akan membentuk satu garis lurus diagonal, dan ploting data residual akan dibandingkan dengan garis diagonal. Jika distribusi data residual normal, maka garis yang menggambarkan data sesungguhnya akan mengikuti garis diagonalnya.

\section{Uji realibilitas}

\begin{tabular}{|c|l|l|l|}
\hline Variabel & $\begin{array}{l}\text { Cronbach's } \\
\text { Alpha }\end{array}$ & $\begin{array}{l}\text { N of } \\
\text { Items }\end{array}$ & Ket \\
\hline Lingkungan kerja & 0,671 & 3 & Reliebel \\
\hline Kepuasan kerja (Y) & 0,803 & 5 & Reliebel \\
\hline Komunikasi (z) & 0,793 & 5 & Reliebel \\
\hline
\end{tabular}

Pada tabel diatas menujukkan bahwa variabel Lingkungan kerja memiliki nilai Cronbach's alpha 0.0.671>0.60, dan variabel Kepuasan kerja memiliki nilai cronbach's alpha 0.803> 0.60 serta Komunikasi memiliki nilai cronbach's alpha 0.793>0.60. Sehingga dari penjelasan tersebut dapat disimpulkan bahwa ke3 variabel dalam penelitian ini yang terdiri dari pernyataan memenuhi standar realibilitas.

\section{Uji normalitas}

One-Sample Kolmogorov-Smirnov Test

\begin{tabular}{|ll|l|}
\hline & & Unstandardized \\
& & Residual \\
\hline $\mathrm{N}$ & Mean & 65 \\
Normal & Std. Deviation & .0000000 \\
Parameter & Absolute & .10196020 \\
Most & & .088 \\
Extreme & Positive & .088 \\
Difference & Negative & -.071 \\
s & .088 \\
Test Statistic & & $.200^{\mathrm{c}, \mathrm{d}}$ \\
Asymp. Sig. (2-tailed) & \\
\hline
\end{tabular}

Berdasarkan tabel diatas menjelaskan bahwa nilai test statistic yaitu $0.088>0.05$ serta nilai signifikansi yaitu $0.200>0.05$, maka dapat disimpulkan bahwa data dalam penelitian ini terdistribusi normal.

\section{Uji multikolonieritas}

Coefficients $^{\mathrm{a}}$

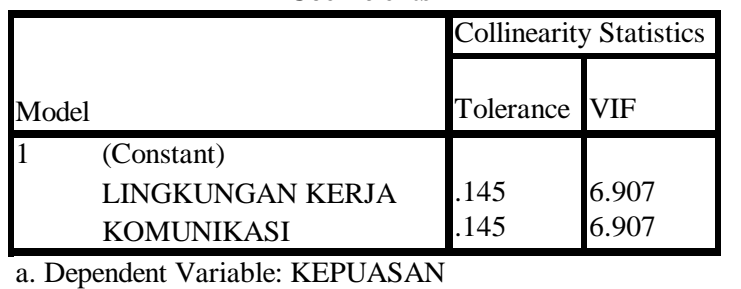


Berdasarkan hasil tabel diatas untuk variabel Lingkungan kerja nilai tolerance yaitu 0.145> 0.10 dan nilai VIF $6.907<10.00$, sedangkan untuk variabel Komunikasi dengan nilai tolerance $0.145>0.10$ dan nilai VIF 6.907< 10.00. Maka dapat di simpulkan bahwa model regresi linear tidak terjadi multikolinearitas.

\section{Uji heteroskedastisitas}

\begin{tabular}{|c|c|c|c|c|c|}
\hline \multicolumn{6}{|c|}{ Coefficients ${ }^{\mathrm{a}}$} \\
\hline \multirow[b]{2}{*}{ Model } & \multicolumn{2}{|c|}{$\begin{array}{l}\text { Unstandardized } \\
\text { Coefficients }\end{array}$} & \multirow{2}{*}{\begin{tabular}{|c|}
$\begin{array}{l}\text { Standardized } \\
\text { Coefficients }\end{array}$ \\
Beta
\end{tabular}} & \multirow[b]{2}{*}{$\mathrm{T}$} & \multirow[b]{2}{*}{ Sig. } \\
\hline & B & \begin{tabular}{|l} 
Std. \\
Error
\end{tabular} & & & \\
\hline (Constant) & .571 & .161 & & 3.553 & .001 \\
\hline LINGKUNGAN KERJA & -.040 & .094 & -.133 & -.422 & .675 \\
\hline KOMUNIKASI & -.061 & .097 & -.198 & -.628 & .532 \\
\hline
\end{tabular}

Berdasarkan hasil pada tabel diatas menujukkan bahwa nilai signifikan pada pengujian heteroskedastisitas untuk variabel lingkungan kerja yaitu 0.675> 0.05, untuk variabel komunikasi 0.532> 0.05.Dapat disimpulkan bahwa model regresi dalam penelitian ini tidak terjadi heteroskedastisitas.

\section{Analisis deskriptif}

\begin{tabular}{|l|l|l|l|l|l|}
\hline \multicolumn{1}{|c|}{ Descriptive Statistics } \\
& $\mathrm{N}$ & Minimum & Maximum & Mean & $\begin{array}{l}\text { Std. } \\
\text { Deviation }\end{array}$ \\
\hline KOMUNIKASI & 65 & 3.27 & 4.87 & 42.986 & .39962 \\
KEPUASAN & 65 & 3.20 & 4.87 & 43.045 & .40742 \\
LINGKUNGAN & & & & & \\
KERJA & 65 & 3.33 & 5.00 & 43.328 & .41216 \\
Valid N (listwise) & 65 & & & & \\
\hline
\end{tabular}

Hasil analisis statistic deskriptif pada table diatas dapat dijelaskan sebagai berikut:

a) Lingkungan kerja (X), Lingkungan kerja dalam penelitian ini menujukan nilai mean yaitu 4.3328 dan nilai standar deviasi yaitu 0.41216, dari hasil tesebut memberikan penjelasan nilai mean > dari nilai standar deviasi sehingga dapat disimpulkan bahwa tingkat variabel lingkungan kerja dalam penelitian ini baik digunakan sebagai representasi data.

b) Kepuasan kerja (Y), Kepuasan kerja dalam penelitian ini menujukan nilai mean yaitu 4.3045 dan nilai standar deviasi yaitu 0.40742 dari hasil tesebut memberikan penjelasan nilai mean > dari nilai standar deviasi sehingga dapat disimpulkan bahwa tingkat variabel kepuasan kerja dalam penelitian ini baik digunakan sebagai representasi data.

c) Komunikasi (Z), Komunikasi dalam penelitian ini menujukan nilai mean yaitu 4.2986 dan nilai standar deviasi yaitu 0.39962 , dari hasil tersebut memberikan penjelasan nilai mean > dari nilai standar deviasi sehingga dapat disimpulkan bahwa tingkat variabel komunikasi
NIAGAWAN Vol 9 No 2 Juli 2020 dalam penelitian ini baik digunakan sebagai representasi data.

Analisis jalur

\begin{tabular}{|l|c|c|c|c|c|}
\hline \multirow{3}{*}{ Model } & \multicolumn{2}{|c|}{$\begin{array}{c}\text { Unst } \\
\text { andardized }\end{array}$} & $\begin{array}{c}\text { Standardized } \\
\text { Coefficients }\end{array}$ & \multirow{2}{*}{$\mathrm{T}$} & \multirow{2}{*}{ Sig. } \\
\cline { 2 - 5 } & $\mathrm{B}$ & $\begin{array}{c}\text { Std. } \\
\text { Error }\end{array}$ & Beta & & \\
\hline 1 (Constant) & .414 & .202 & & 2.045 & .045 \\
LINGKUNGAN KERJA & .897 & .046 & .925 & 19.292 & .000 \\
\hline
\end{tabular}

Pada table diatas terlihat bahwa nilai standardized coefficients yang merupakan koefisien jalur variabel lingkungan kerja (X). Dari tabel diatas dapat disusun matriks koefisien jalur sebagai berikut $:(\rho z x)=(0.925)$ dan dapat di hitung $\varepsilon_{1}=0.3807$.

\begin{tabular}{|l|l|l|l|l|l|}
\hline \multirow{5}{*}{ Model } & \multicolumn{2}{|l|}{ Coefficients $^{\mathrm{a}}$} \\
& $\begin{array}{l}\text { Unstandardized } \\
\text { Coefficients }\end{array}$ & $\begin{array}{l}\text { StandardizdCoe } \\
\text { fficients }\end{array}$ & \multirow{2}{*}{$\mathrm{T}$} & Sig. \\
\cline { 2 - 5 } & $\mathrm{B}$ & Std. Error & Beta & & \\
\hline 1 (Constant) & .597 & .256 & & 2.330 & .023 \\
LINGKUNGAN KERJA & -.480 & .150 & -.486 & -3.205 & .002 \\
KOMUNIKASI & 1.347 & .155 & 1.321 & 8.711 & .000 \\
\hline
\end{tabular}

Pada table diatas terlihat bahwa nilai standardized coefficients yang merupakan koefisien jalur variabel lingkungan kerja (X) dan komunikasi (Z). Dari tabel diatas dapat disusun matriks koefisien jalur sebagai berikut $:\left(\begin{array}{c}\rho y x \\ \rho y z\end{array}\right)=\left(\begin{array}{c}-0.486 \\ 1.321\end{array}\right)$ dan dapat di hitung $\varepsilon_{2}=$ 0.4538 .

Dari kedua tabel diatas maka dapat di peroleh diagram jalur sebagai berikut:

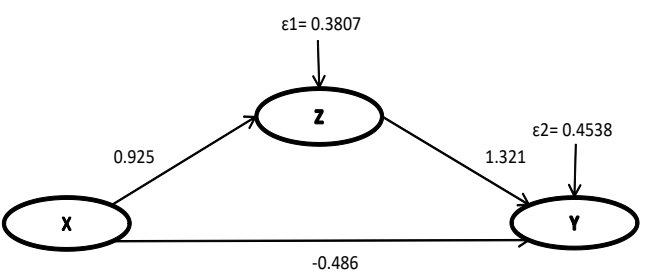

Uji determinasi $\left(\mathbf{R}^{2}\right)$

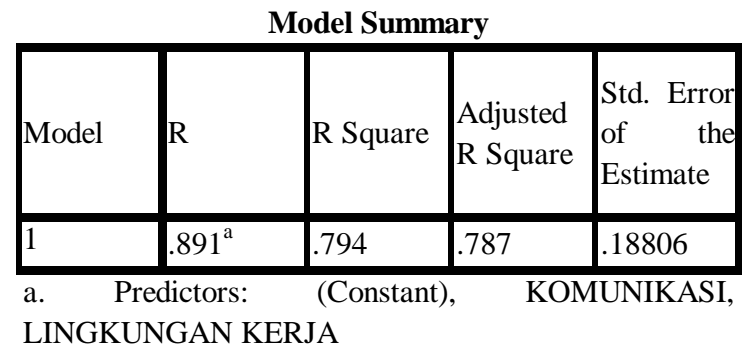

Tabel di atas menunjukkan nilai determinasi (Adjusted R square) hasil hitung adalah sebesar 0,787. Nilai tersebut menunjukkan bahwa kedua variabel bebas dalam penelitian ini mampu menjelaskan variabel terikatnya sebesar $78.7 \%$, 
di mana sisanya yaitu sebesar $21.3 \%$ dijelaskan oleh faktor lain di luar penelitian ini.

\section{Uji simultan (uji f)}

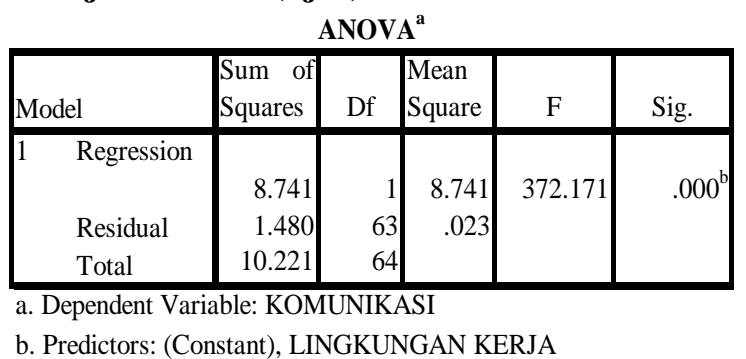

Tabel diatas menunjukkan bahwa hasil uji $F$ yaitu $f_{\text {tabel }}>f_{\text {hitung }}(372.171>1.9983)$ dan nilai signifkan sebesar 0,000 .Hal ini berarti lingkungan kerja berpengaruh positif dan signifikan terhadap kepuasan pegawai.

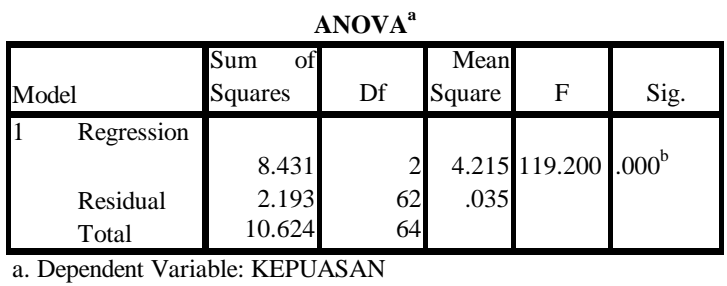

b. Predictors: (Constant), KOMUNIKASI, LINGKUNGAN KERJA

Tabel diatas menunjukkan bahwa hasil uji $F$ yaitu $f_{\text {tabel }}>f_{\text {hitung }}(199.200>1.9989)$ dan nilai signifkan sebesar 0,000 . Hal berarti seluruh variabel endogen, yaitu lingkungan kerja dan komunikasi secara simultan memiliki pengaruh terhadap kepuasan.

Uji parsial (uji t)

\begin{tabular}{|c|c|c|c|c|c|}
\hline & \multicolumn{3}{|c|}{ Coefficients $^{\mathrm{a}}$} & \multirow[b]{3}{*}{$\mathrm{t}$} & \multirow[b]{3}{*}{ Sig. } \\
\hline \multirow[b]{2}{*}{ Model } & $\begin{array}{r}\text { Unst } \\
\mathrm{Co}\end{array}$ & $\begin{array}{l}\text { andardized } \\
\text { efficients }\end{array}$ & $\begin{array}{l}\text { Standardized } \\
\text { Coefficients }\end{array}$ & & \\
\hline & $\bar{B}$ & Std. Error & Beta & & \\
\hline 1 (Constant) & .414 & .202 & & 2.045 & .045 \\
\hline $\begin{array}{l}\text { LINGKUNGAN } \\
\text { KERJA }\end{array}$ & .897 & .046 & .925 & & .000 \\
\hline
\end{tabular}

Berdasarkan tabel diatas dapat dilihat yaitu pada nilai $\mathrm{t}$ dengan nilai $\mathrm{df}=\mathrm{n}-\mathrm{k}-1=65-2-1=$ 62, maka $t_{\text {hitung }}$ diperoleh pada lampiran yaitu 1.998. Pada tabel diatas menunjukkan hasil bahwa variabel lingkungan kerja dengan nilai $\mathrm{t}_{\text {tabel }}>\quad \mathrm{t}_{\text {hitung }}(19.292>1.9989) \quad$ dan tingkat signifikan lebih kecil dari $0.05(0.000<0.05)$, yang berarti Ho diterima sehingga dapat dikatakan bahwa lingkungan kerja berpengaruh signifikan secara parsial terhadap komunikasi.

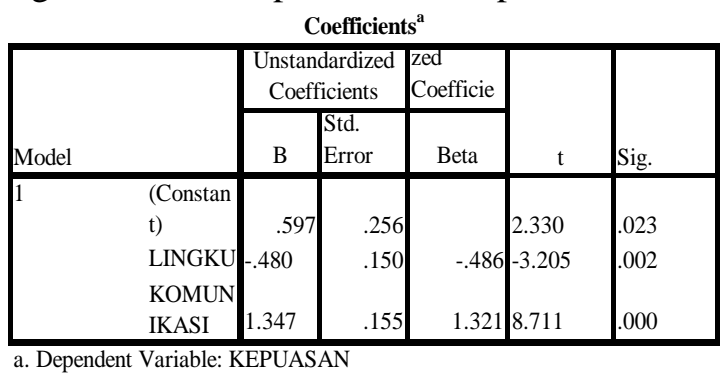

NIAGAWAN Vol 9 No 2 Juli 2020

Berdasarkan tabel 4.22 diatas dapat dilihat yaitu pada nilai $\mathrm{t}$ dengan nilai $\mathrm{df}=\mathrm{n}-\mathrm{k}-1=65-2-1=$ 62, maka $t_{\text {tabel }}$ diperoleh pada lampiran yaitu 1.998. Pada tabel diatas menunjukkan hasil bahwa variabel lingkungan kerja dengan nilai $\mathrm{t}_{\text {tabel }}>\mathrm{t}_{\text {hitung }}(-3.205<1.998)$ dan tingkat signifikan lebih kecil dari $0.05(0.02<0.05)$, yang berarti Ho di tolak. diterima sehingga dapat dikatakan bahwa lingkungan kerja berpengaruh negatif signifikan secara parsial terhadap kepuasan. Sedangkan variabel komunikasi dengan nilai $\mathrm{t}_{\text {tabel }}>\mathrm{t}_{\text {hitung }}(8.771>1.998)$ dan nilai signifikan lebih kecil dari $0.05(0.000<0.05)$, maka dapat disimpulkan bahwa $\mathrm{H}_{0}$ diterima.Yang berarti komunikasi berpengaruh signifikan secara parsial terhadap kepuasan.

\section{INTERPRETASI PEMBAHASAN \\ Pengaruh lingkungan kerja terhadap komunikasi.}

Berdasarkan pengujian coefficient regresi menunjukkan nilai signifikan $0,000<0,05$ dan $\mathrm{t}$ $=19,292$ yang lebih besar dari titik kritis 1.998 . Dengan demikian dari hasil pengujian koefisien jalur dapat disimpulkan bahwa koefisien jalur X ke $\mathrm{Z}$ secara statistik adalah signifikan ( $\mathrm{t}_{\text {tabel }}$ lebih

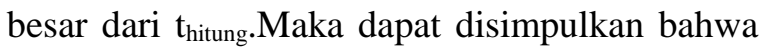
lingkungan kerja mempunyai pengaruh positif signifikan terhadap komunikasi.Faktor penyebab positif dan signifikan lingkungan kerja terhadap komunikasi pada dinas perhubungan karena dengan adanya komunikasi yang baik dengan rekan sekerja maupun komunikasi antara atasan dan bawahan mampu membuat pegawai merasa puas dalam melakukan segala jenis pekerjaanya.

Penelitian ini sejalan dengan penelitian terdahulu yang dilakukan oleh Firsta Riopras Rinaldi (2018) yang menyimpulkan bahwa lingkungan kerja berpengaruh signifikan terhadap komunikasi seluruh karyawan CV Isa Grafika Semarang.

\section{Pengaruh lingkungan kerja terhadap kepuasan pegawai}

Berdasarkan pengujian coefficient regresi menunjukkan nilai signifikan $0,000<0,05$ dan $\mathrm{t}$ $=-3.205$ yang lebih besar dari titik kritis 1.998 . Dengan demikian dari hasil pengujian koefisien jalur dapat disimpulkan bahwa koefisien jalur X ke $\mathrm{Y}$ secara statistik adalah signifikan ( $\mathrm{t}_{\text {tabel }}$ lebih

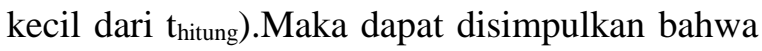
lingkungan kerja mempunyai pengaruh negative signifikan terhadap kepuasan kerja). Faktor penyebab negative dan signifikan lingkungan kerja terhadap kepuasan pegawai karena adanya rasa kurang Nyman pegawai pada 
lingkungannya baik itu dari segi lingkungan kerja fisik maupun dari segi lingkungan kerja non fisik, misalnya fasilitas bekerja yang masih kurang memadai dan suasana tempat mereka bekerja yang di rasa belum cukup memadai.

Penelitin ini sejalan dengan penelitian terdahulu yang di lakukan oleh Al Musadieq dan Eko (2014) dengn objek penelitian PT. Telkom Indonesia Tbk, yang menyimpulkan bahwa lingkungan kerja fisik dan non fisik secara bersama-sama berpengaruh signifikan terhadap kepuasan kerja karyawan.

\section{Pengaruh komunikasi terhadap kepuasan pegawai}

Berdasarkan pengujian coefficient regresi menunjukkan nilai signifikan $0,000<0,05$ dan $\mathrm{t}$ $=8.711$ yang lebih besar dari titik kritis 1.998 . Dengan demikian dari hasil pengujian koefisien jalur dapat disimpulkan bahwa koefisien jalur Z ke $Y$ secara statistik adalah signifikan ( $t_{\text {tabel }}$ lebih besar dari $t_{\text {hitung }}$ ).Maka dapat disimpulkan bahwa komunikasi mempunyai pengaruh positif signifikan terhadap kepuasan kerja).Faktor penyebab positif dan signifikan komunikasi terhadap kepuasan pegawa Dinas Perhubungan diakibatkan karena komunikasi antar pegawai antar pegawai terjalin dengan baik sehingga pegawai merasa puas dalam bekerja.

Penelitian ini sejalan dengan penelitian terdahulu yang di lakukan oleh Okta (2016) telah menyimpulkan bahwa komunikasi dapat meningkatkan kepuasan kerja karyawan PT. Pabrik Kertas Setia Kawan Makmur Sejahtera Tulungangung.

\section{Pengaruh lingkungan kerja terhadap kepuasan kerja melalui komunikasi}

Analisis pengaruh $\mathrm{X}$ ke $\mathrm{Y}$ melalui Zdiketahui pengaruh langsung yang diberikan $\mathrm{X}$ terhadap $\mathrm{Y}$ sebesar -0.486 Sedangkan pengaruh tidak langsung $\mathrm{X}$ melalui $\mathrm{Z}$ terhadap $\mathrm{Y}$ adalah perkalian nilai beta $X$ terhadap $Z$ dengan nilai beta $\mathrm{Z}$ terhadap $\mathrm{Y}$ yaitu $: 0.925 \mathrm{X} 1.321=1.221$ Maka pengaruh total yang diberikan $X$ terhadap $\mathrm{Y}$ adalah pengaruh langsung ditambah dengan pengaruh tidak langsung yakni : $-0.486+1.221$ $=1.707$. Ini menunjukkan bahwa secara tidak langsung $\mathrm{X}$ melalui $\mathrm{Z}$ mempunyai pengaruh positif signifikan terhadap Y.

Penelitian ini sejalan dengan penelitian yang di lakukan oleh Rinaldi dan Heru (2018) dengan judul gaya kepemiminan, jenjang karir, lingkungan kerja terhadap kepuasan kerja dengan komunikasi sebagai variabel intervening, yang menyimpulkan bahwa lingkungan kerja berpengaruh signifikan terhadap kepuasan kerja melalui komunikasi pada CV. Isa Grafika Semarang.

\section{KESIMPULAN}

Berdasarkan analisis secara parsial (ujit), ternyata hasil penelitian membuktikan bahwa variabel independen, yaitu lingkungan kerja(X) berpengaruh positif dan signifikan secara parsial terhadap komunikasi(Z) pada Dinas Perhubungan Kota Makassar, maka dinyatakan hipotesis pertama diterima, Variabel independen, yaitu lingkungan kerja $(\mathrm{X})$, berpengaruh negatif dan signifikan secara parsial terhadap kepuasan pegawai(Y)maka dinyatakan hipotesis kedua ditolak, Variabel mediasi yaitu komunikasi (Z) berpengaruh positif dan signifikan secara parsial terhadap kepuasan pegawai(Y)maka dinyatakan hipotesis ketiga diterima.

Berdasarkan hasil analisis jalur, ternyata hasil penelitian membuktikan bahwa variabel independen, yaitu lingkungan kerja (X), berpengaruh positif dan signifikan secara parsial terhadap kepuasan pegawai(Y) melalui variabel mediasi yaitu komunikasi (Z). pada Dinas Perhubungan Kota Makassar, maka dinyatakan hipotesis keempat diterima.

\section{SARAN}

Berdasarkan kesimpulan diatas, maka saran pada penelitian ini adalah (1) Bagi peneliti selanjutnya diharapkan dapat meneliti dengan variabel-variabel lain di luar variabel yang telah diteliti ini agar memperoleh hasil yang lebih bervariatif yang dapat berpengaruh terhadap kepuasan pegawai, (2) Bagi Instansi, sebaiknya instansi harus mampu memberikan kepuasan yang lebuh besar lagi kepada pegawainya dengan meningkatkan lingkungan kerja yang baik, baik itu lingkungan kerja fisik maupun lingkungan kerja non fisik, serta meningkatkan komunikasi yang baik antara pimpinan dan bawahan maupun sesame rekan kerja, (3) Bagi pegawai,sebaiknya dapat membantumenciptakan lingkungan kerja yang aman dan nyaman serta meningkatkan komunikasi yang semakin baik sehingga bisa mencapai kepuasan kerja dandapat mengungtungkan pegawai dan instansi.

\section{REFERENCES}

Kasmir. (2016). Manajemen Sumber Daya Manusia (Teori Dan Praktik). Jakarta: PT Raja Grafindo Persada. 
Mangkunegara. (2014). Manajemen Sumber

Daya Manusia. Bandung: PT Remaja Rosdakarya.

Muhammad. (2011). Pengaruh Komunikasi Internasional Terhadap Kinerja Pegawai Pada Fakultas Ekonomi Universitas PGRI Palembang. Benny Usman .

Nitisemito. (1992). Pengaruh Budaya Organisaisi Dan Lingkungan Kerja Terhadap Kinerja Karyawan Koperasi Serba Usaha Setya Usaha Di Kabupaten Jepara. Gogy Bara Kharisma .

Sedarmayati. (2011). Gaya Kepemimpinan, Jenjang Karir, Lingkungan Kerja Terhadap Kepuasan Kerja Dengan Komunikasi Sebagai Variabel Intervening Pada CV Isa Grafika Semarang. FR Rinaldi, HS Wulan, MM Minarsih .

Siagian, S. P. (2014). Manajemen Sumber Daya Manusia. Jakarta: Bumi Aksara.

Sugiyono. (2017). Metode Penelitian Kuantitatif, Kualitatif, dan $R \& O$. Bandung: CV Alfabeta.

Sutrisno, E. (2015). Manajemen Sumber Daya Manusia. Jakarta: Kencana.

Wibowo. (2013). Gaya Kepemimpinan, Jemjamg Karir, Lingkungan Kerja Terhadap Ksepuasan Kerja Dengan Komunikasi Sebagai Variabel Intervening Pada CV Isa Grafika Semarang. FR Rinaldi, HS Wulan, MM Minarsih .

Robbins, P. F., Kassim, S. H., Tran, T. L., Crystal, J. S., Morgan, R. A., Feldman, S. A., ... \& Kammula, U. S. (2015). A pilot trial using lymphocytes genetically engineered with an NY-ESO-1-reactive T-cell receptor: long-term follow-up and correlates with response. Clinical Cancer Research, 21(5), 1019-1027 